\title{
Direct Fuel Cell/Turbine Power Plant
}

Technical Progress Report

For

Period 11/1/2002 through 4/30/2003

May 27, 2003

Hossein Ghezel-Ayagh, Principle Investigator

Prepared for:

U.S. Department of Energy

National Energy Technology Laboratory

P.O. BOX 10940

Pittsburgh, PA 15236-0940

DOE Grant NO. DE-FC26-00NT40798

Prepared by:

FuelCell Energy, Inc.

3 Great Pasture Road

Danbury, CT 06813 


\section{Disclaimer}

"This report was prepared as an account of work sponsored by an agency of the United States Government. Neither the United States Government nor any agency thereof, nor any of their employees, makes any warranty, express or implied, or assumes any legal liability or responsibility for the accuracy, completeness, or usefulness of any information, apparatus, product, or process disclosed, or represents that its use would not infringe privately owned rights. Reference herein to any specific commercial product, process, or service by trade name, trademark, manufacturer, or otherwise does not necessarily constitute or imply its endorsement, recommendation, or favoring by the United States Government or any agency thereof. The views and opinions of authors expressed herein do not necessarily state or reflect those of the United States Government or any agency thereof." 


\begin{abstract}
The subMW hybrid DFC/T power plant facility was upgraded with a Capstone C60 microturbine and a state-of-the-art full size fuel cell stack. The integration of the larger microturbine extended the capability of the hybrid power plant to operate at high power ratings with a single gas turbine without the need for supplementary air. The objectives of this phase of subMW hybrid power plant tests are to support the development of process and control and to provide the insight for the design of the packaged subMW hybrid demonstration units.

The development of the ultra high efficiency multi-MW power plants was focused on the design of $40 \mathrm{MW}$ power plants with efficiencies approaching 75\% (LHV of natural gas). The design efforts included thermodynamic cycle analysis of key gas turbine parameters such as compression ratio.
\end{abstract}




\section{TABLE OF CONTENTS}

\section{Page No.}

$\begin{array}{lll}1.0 & \text { EXPERIMENTAL } & 1\end{array}$

2.0 RESULTS AND DISCUSSIONS 2

$\begin{array}{lll}3.0 & \text { CONCLUSION } & 8\end{array}$

$\begin{array}{lll}4.0 & \text { REFERENCES } & 8\end{array}$ 


\subsection{EXPERIMENTAL}

The modification of the subMW power plant was continued for the next phase of operation of a $250 \mathrm{~kW}$ fuel cell stack integrated with the Capstone C60 microturbine. The progress included completion of the piping and insulation of the balance-of-plant (BOP) equipment. The operation of the microturbine was checked out. The instrumentation of the power plant was completed. Continuity tests were performed to check out the functionality of the instruments. Prior to installation of the fuel cell stack, the process and control tests of BOP including the microturbine were performed. Various power plant operational modes were tested successfully including start-up, open circuit voltage, and plant trip with simulated gas environment. The objectives of these tests were to ensure the functionality of the equipment, instrumentation and control, and the procedures prior to the installation of the stack.

Upon completion of the process and control tests, the fuel cell stack was connected to the BOP and operation of the hybrid subMW DFC/T system was initiated. The operation of the subMW DFC/T with a Capstone C60 microturbine was demonstrated at high power ratings in grid-connected mode with a dc-to-ac inverter and the microturbine connected to the grid in parallel. Figure 1 shows a picture of the DFC/T power plant facility with the $\mathrm{C} 60$ microturbine integrated in the fuel cell system.

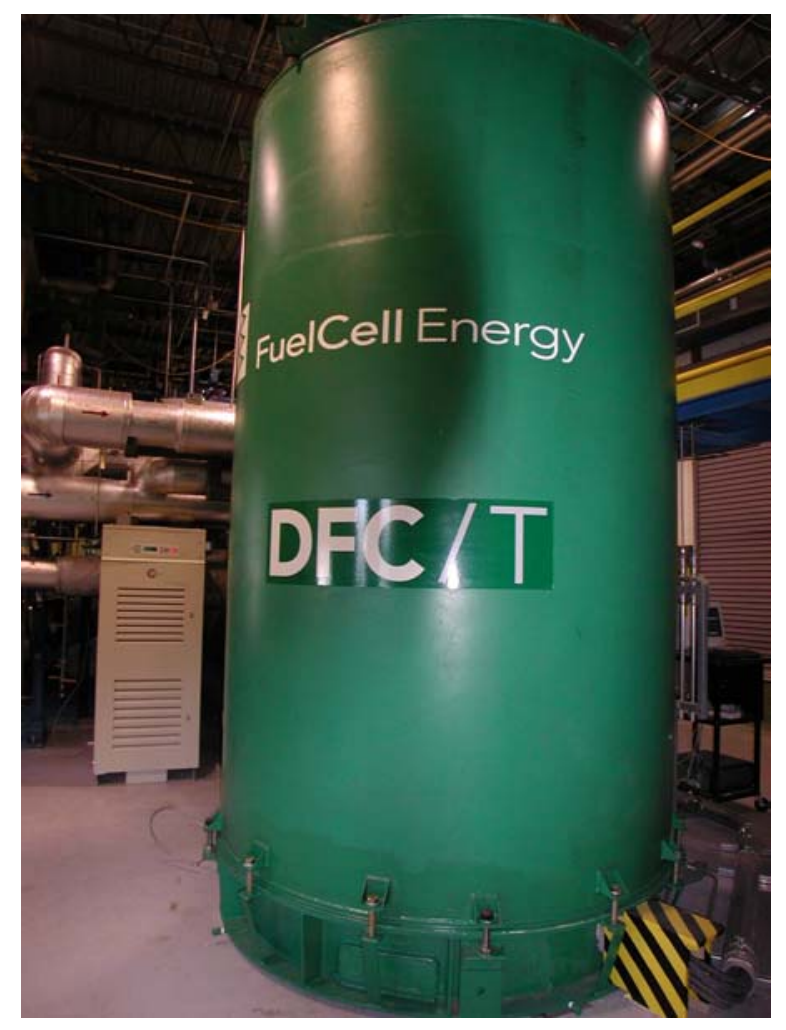

Figure 1. subMW DFC/T Hybrid Power Plant Integrated with Capstone C60 


\subsection{RESULTS AND DISCUSSIONS}

\section{SubMW Design:}

The subMW hybrid tests are primarily focused on the power plant operation and control logic in support of the design activities for the subMW hybrid package. The operational tests as well as the tests of the power plant heat-up accomplished during the process and control checkout of the balance-of-plant confirmed the stable and well-controlled operation of the DFC/T power plant with a single gas turbine. The microturbine was utilized as the only source for supplying fresh air to the system without the need for supplementary air by any other source such as an air blower.

In this reporting period the power plant benchmarked the operation at $\sim 250 \mathrm{~kW}$ in grid connected mode with a dc-to-ac inverter and the microturbine connected to the grid in parallel.

\section{Multi-MW Design:}

The development of the $40 \mathrm{MW}$ hybrid power plant design was continued. One of the key features of the DFC/T power cycle is its adaptability in incorporating a wide range of the existing gas turbine frames with minimal hardware modifications consisting of gas inlet/outlet ports. Compared with the microturbine used in the sub-MW DFC/T power plants, MW-sized gas turbines are designed to operate at high-pressure ratios and high air flow rates. The MW-sized gas turbines have higher specific power and efficiency. However, the net gain in performance (overall system efficiency) and the incremental cost due to integration of the gas turbine depend on a multitude of design variables such as gas turbine pressure ratio (PR), turbine inlet temperature (TIT), and heat recuperator temperature and materials. A basic study was performed to clarify the impact of these parameters on the performance of DFC/T power plants. The results of this fundamental study, as described here, is used to set forth the criteria for selection of the existing gas turbines and the guidelines for R\&D needs for the ultra high efficiency DFC/T power plants.

The study consists of an indirectly heated Brayton cycle (open cycle). The compressor was assumed to be a two-stage compressor with intercooling in between. The compressor isentropic efficiency was assumed to be $84 \%$ for each stage and the turbine isentropic efficiency was $90 \%$. The computer simulations were carried out using ChemCad process simulation software (Chemstations, Inc).

Figure 2 shows the effects of PR and TIT on the gas turbine performance. The intercooling for the compressor reduces the compressor power consumption, which leads to a higher gas turbine efficiency at high-pressure ratios, especially for low TIT cases. As expected, the gas turbine specific work increases with increasing TIT. The specific work does not drop significantly with PR in the high-pressure ratio range for each constant TIT curve as illustrated in Figure 2. 


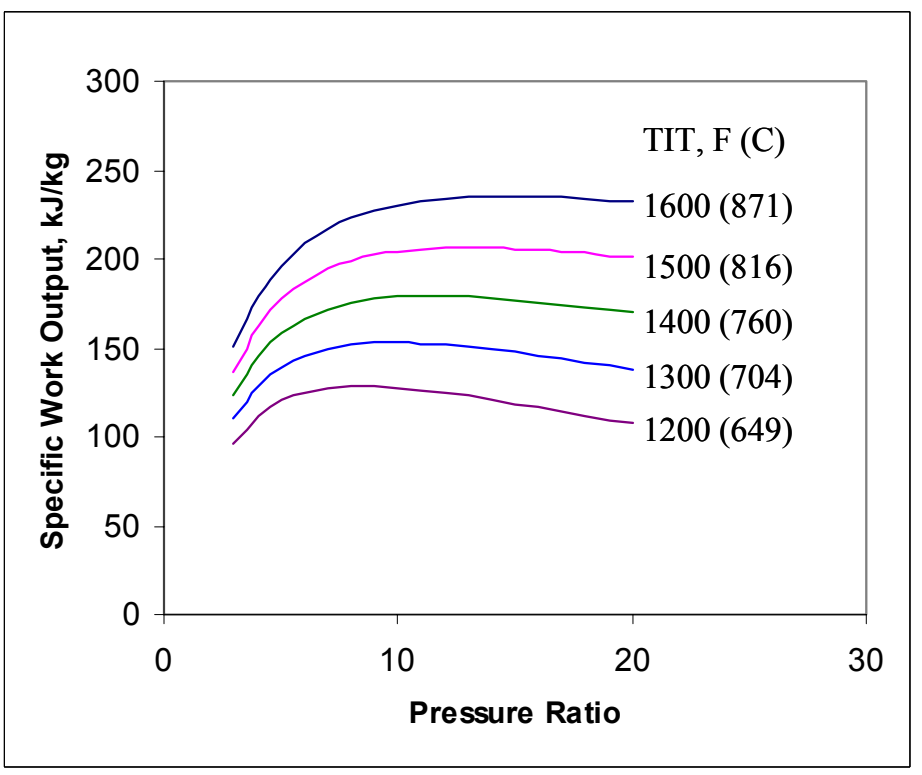

Figure 2. Specific Work Output as a Function of Pressure Ratio and Turbine Inlet Temperature for Indirectly Heated Inter-Cooled Gas Turbine

Figures 3 shows the dependency of the gas turbine efficiency on PR and TIT. The results show that for a given gas turbine design (fixed pressure ratio), the gas turbine is more efficient in conversion of the recuperated heat to useful work at higher turbine inlet temperatures.

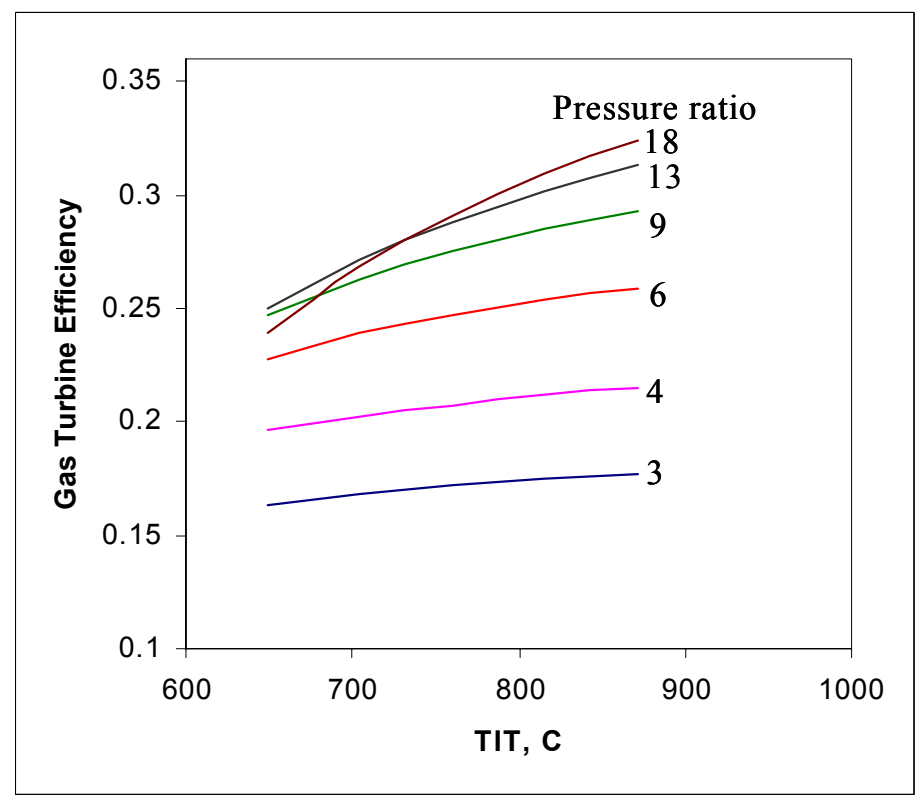

Figure 3. Gas Turbine Efficiency as a Function of Pressure Ratio and Turbine Inlet Temperature for Indirectly Heated Inter-cooled Gas Turbine 
Figure 4 shows a simplified design concept for the $40 \mathrm{MW}$ power plant design with a two-stage intercooled compressor. The system performance summary is shown in Table 1. The gas turbine is assumed to have an isentropic efficiency of $87 \%$ for compression and $93 \%$ for expansion with an overall compression ratio of about 1:9.

In this system, the natural gas fuel is humidified in a heat recovery unit utilizing the waste heat from the fuel cell cathode off-gas. The humidified fuel is then superheated in the heat recovery unit before entering the fuel cell anode. The air is compressed in the two-stage compression section of the gas turbine and is heated in two recuperators before entering the turbine section. The expanded turbine air is then mixed with the fuel cell anode off-gas before entering the anode gas oxidizer (AGO). The AGO effluent is cooled to provide the heat to the compressed turbine air prior to entering to the fuel cell cathode. The cathode-off gas is used in the heat recovery section to heat the turbine air and provide heat for fuel humidification.

Table 1. The Performance characteristics of the $40 \mathrm{MW}$ ultra high efficiency system (Configuration 1)

\begin{tabular}{|l|r|}
\hline & $\begin{array}{c}\text { With Intercooled } \\
\text { Gas Turbine }\end{array}$ \\
\hline Fuel Cell: & 33.55 \\
DC Power Out, MW & 32.71 \\
AC Power Out, Gross, MW & \\
Gas Turbine: & $(10.73)$ \\
Compressor Power, MW & 20.97 \\
Expander Power, MW & 9.73 \\
Net AC Out, MW & $(0.22)$ \\
Auxiliary Power Consumption, MW & 42.22 \\
Net Power Output, MW & 55.89 \\
Fuel Heating Value, MW & $75.6 \%$ \\
\hline
\end{tabular}




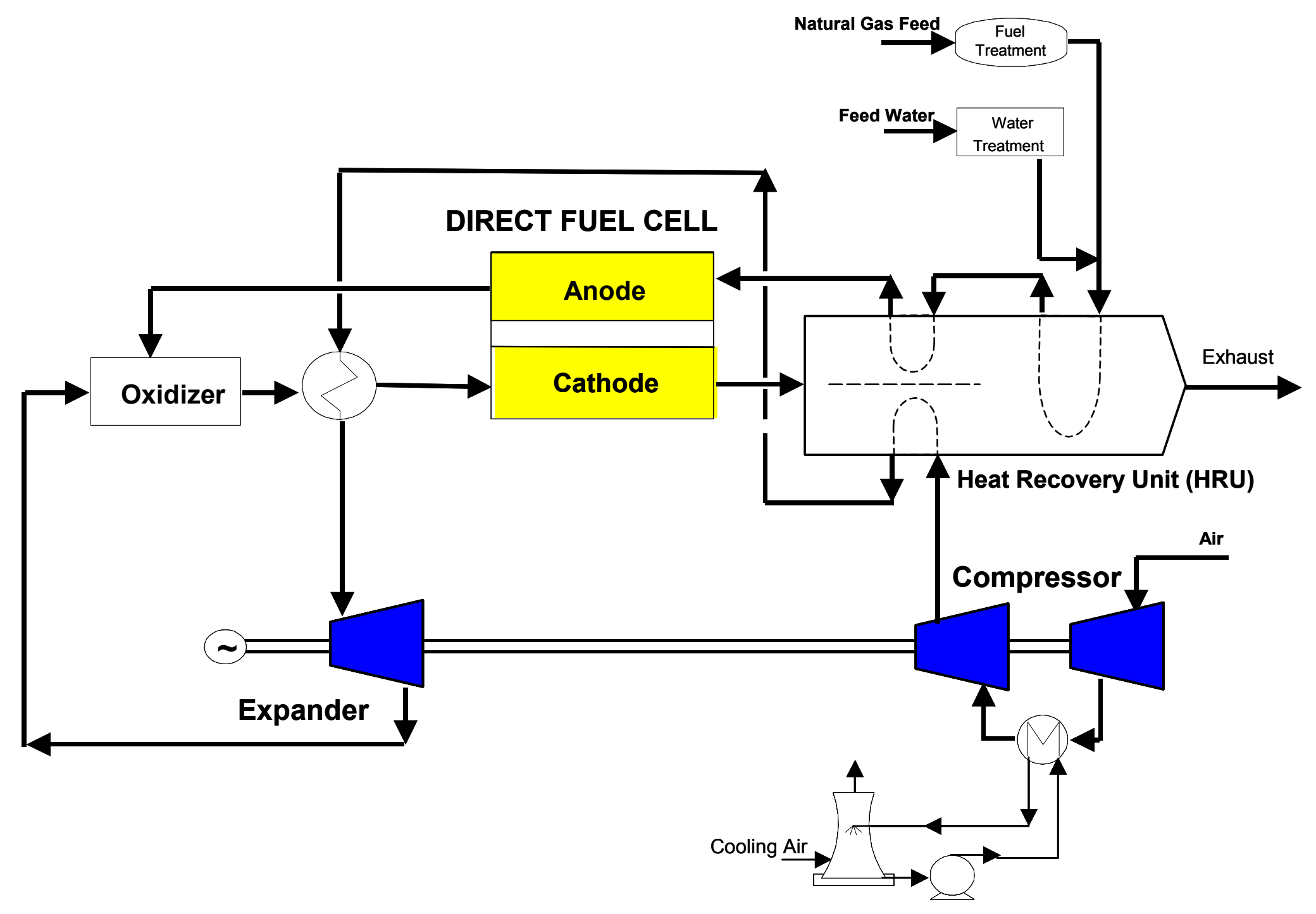

Figure 4. 40 MW Power Plant Design with Intercooled Gas Turbine (Configuration 1) 
An alternative system configuration, shown in Figure 5, was also developed. In this design, a multi-stage reheat cycle is implemented in the expansion section of the gas turbine. The addition of the re-heat section lowers the recuperation temperature and thus has the potential for lowering the cost of the power plant. The net system efficiency of the system is about $75 \%$ assuming a gas turbine with isentropic efficiencies of $87 \%$ for compression and $93 \%$ for expansion and an overall compression ratio of $1: 9$. The breakdown of the power generation (and consumption) of the $40 \mathrm{MW}$ hybrid power plant utilizing both intercooled and re-heat cycles is summarized in Table 2.

Table 2. The Performance characteristics of the 40MW ultra high efficiency system (Configuration 2)

\begin{tabular}{|l|r|}
\hline & $\begin{array}{r}\text { With Intercooled } \\
\text { Gas Turbine }\end{array}$ \\
\hline Fuel Cell: & 33.55 \\
DC Power Out, MW & 32.71 \\
AC Power Out, Gross, MW & \\
Gas Turbine: & $(10.73)$ \\
Compressor Power, MW & 20.68 \\
Expander Power, MW & 9.46 \\
Net AC Out, MW & $(0.22)$ \\
Auxiliary Power Consumption, MW & 41.95 \\
Net Power Output, MW & 55.89 \\
Fuel Heating Value, MW & $75.1 \%$ \\
\hline
\end{tabular}




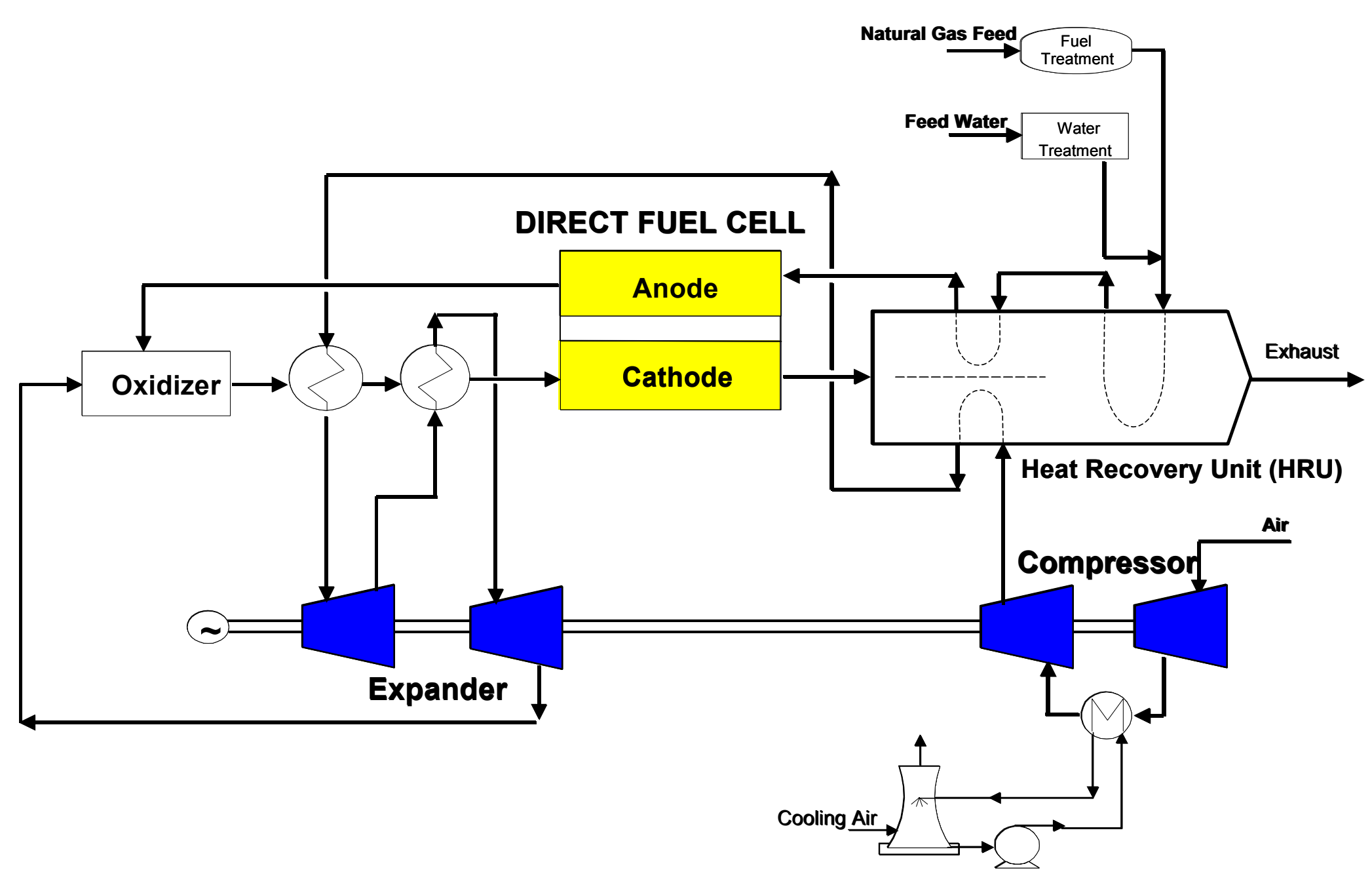

Figure 5. 40 MW Power Plant Design with Intercooled and Re-heat Gas Turbine (Configuration 2) 


\subsection{CONCLUSION}

The results of the fundamental analysis for the Multi-MW design have shown that the gas turbines with inter-cooled compression and high-pressure ratios are candidates for achieving ultra high efficiencies approaching 75\% (LHV, natural gas). However DFC/T systems can also utilize the existing gas turbines in the market at reduced efficiency. The heat rate and the cost of these systems can be optimized depending on the gas turbine pressure ratio and design parameters such as turbine inlet temperature.

The results of the SubMW design tests confirm the stability and controllability of operating the $250 \mathrm{~kW}$ fuel cell in combination with a microturbine. The results also confirmed the ability of the microturbine to supply adequate air to the DFC/T power plant.

\subsection{REFERENCES}

H. Ghezel-Ayagh, J. Daly, and Z. Wang, "Advances in Direct FuelCell / Gas Turbine Power Plants," To be published in Proceedings of ASME/IGTI Turbo Expo 2003, ASME paper GT2003-38941. 